\title{
Ceramide-1-Phosphate Transfer Protein
}

National Cancer Institute

\section{Source}

National Cancer Institute. Ceramide-1-Phosphate Transfer Protein. NCI Thesaurus. Code C113112.

Ceramide-1-phosphate transfer protein (214 aa, $\sim 24 \mathrm{kDa}$ ) is encoded by the human CPTP gene. This protein is involved in intercellular transport of sphingolipids. 